\title{
A representação da pobreza urbana no livro didático de geografia do ensino médio
}

\author{
The representation of urban poverty in high school geography textbooks
}

\author{
Débora Luzia Moura Correial; Jacqueline Praxedes Almeida"
}

\section{RESUMO}

O presente Trabalho é um estudo voltado para a temática da pauperização que acomete os habitantes do meio urbano. Sendo a pobreza e a escola muitas vezes relacionadas pelas condições socioeconômicas dos próprios estudantes, se faz necessário que a temática seja tratada em sala de aula. Para tanto, o Livro Didático é um importante recurso, pois apresenta os conteúdos de maneira sistematizada para professores e alunos. Diante do exposto, o presente o artigo tem por objetivo apresentar a análise feita em duas coleções de Livros Didáticos de Geografia do Ensino Médio aprovados no Programa Nacional do Livro Didático (PNLD) de 2018, buscando identificar a representação da pobreza nos mesmos. A pesquisa foi, de cunho qualitativo e desenvolvida a partir da revisão bibliográfica e análise de Livros Didáticos, buscando identificar a representação da pobreza nos mesmos. A investigação revelou que a temática, apesar de presente nas coleções, não é encontrada em todos os volumes. Também foi possível verificar que a Pobreza é tratada nos livros de formas variadas, sendo utilizado para tanto, imagens, textos, charges e gráficos. A abordagem do tema é feita em grande parte sob uma perspectiva crítica, mostrando causas e consequências da pobreza urbana, além de apresentar situações que estimulam os alunos a refletirem sobre a temática. No entanto, a ênfase dada ao tema nas coleções é bem distinta.

Palavras-chave: Ensino Médio; Livro Didático de Geografia; Representação da Pobreza

\section{ABSTRACT}

The present work is a study focused on the theme of impoverishment that affects the inhabitants of the urban environment. Since poverty and school are often related to the socioeconomic conditions of the students themselves, it is necessary that the topic be addressed in the classroom. For that, the Didactic Book is an important resource, as it presents the contents in a systematic way for teachers and students. Based on that, this article aims to present the analysis made in two collections of High School Geography Textbooks approved in the 2018 National Textbook Program (PNLD in portuguese), seeking to identify the representation of poverty in them. The research have a qualitative nature and was developed based on bibliographic review and analysis of Didactic Books, seeking to identify the representation of poverty in them. The investigation revealed that the theme, although present in the collections, is not found in all volumes. It was also possible to verify that Poverty is treated in books in different ways, being used for this purpose, images, texts, cartoons and graphics. The theme is approached largely from a critical perspective, showing the causes and consequences of urban poverty, in addition to presenting situations that encourage students to reflect about the theme. However, the emphasis given to the theme in the collections is quite different.

Keywords: High School; Geography Textbook; Representation of Poverty

' Universidade Federal de Alagoas, Alagoas, Brasil, https://orcid.org/0000-0003-1771-4803 - deboraluziamc@gmail.com 


\section{INTRODUÇÃO}

O Brasil é um país que se caracteriza por apresentar baixo investimento de recursos públicos por aluno, por não ter ainda conseguido colocar todas as crianças e adolescentes na escola e por apresentar uma remuneração aos professores muito aquém da de outros profissionais com a mesma qualificação. Todos esses fatores impactam diretamente na qualidade do ensino ofertado, contribuindo para o acirramento das desigualdades.

Nesse contexto, destacam-se as condições socioeconômicas como importantes influenciadoras do processo de escolarização, interferindo na aprendizagem das crianças e jovens e, assim, em seu desempenho escolar (ALMEIDA, 2017). Pode-se afirmar que a pobreza e a escola estão intimamente relacionadas às condições socioeconômicas dos próprios estudantes, muitas vezes, interferindo na aprendizagem escolar.

A pobreza é um fenômeno complexo e com múltiplos desdobramentos dentro das sociedades capitalistas, pois as desigualdades socioeconômicas, em particular as de renda, afetam a qualidade de vida, acarretando também desigualdades educacionais. Portanto, as possibilidades de redução da pobreza perpassam a democratização de um ensino de qualidade, que possibilita a ascensão socioeconômica. Assim,

como pensar currículos, conteúdos e metodologias, como formular políticas e planejar programas educativos sem incorporar os estreitos vínculos entre as condições em que os educandos reproduzem suas existências e seus aprendizados humanos? (ARROYO, 2003, p. 32).

Nesse sentido, a representação da pobreza nos conteúdos de Geografia do Ensino Médio está atrelada a assuntos que caminham para uma discussão sobre o sistema capitalista, as classes sociais, as formas de organização e de formação do 
espaço geográfico, os índices de desenvolvimento, a desigualdade socioeconômica, a industrialização e urbanização, a globalização e o subdesenvolvimento, entre outros.

A Geografia, enquanto disciplina escolar, deve buscar elucidar as relações espaciais existentes, dentre as quais se insere o entendimento da produção da pobreza como fruto do desenvolvimento desigual e combinado da realidade (SAAB, 2018), para tanto, deve se opor a chamada pedagogia bancaria, que segundo Freire (2018), atua no sentido de formar indivíduos dóceis e submissos aos valores vigentes.

Para promover uma educação que possibilite a autonomia do educando, o professor de Geografia deve incluir nas suas aulas, as vivências dos discentes, trabalhando, a partir delas, como ocorre a produção política, histórica, social e econômica da pobreza, de modo a ajudar aos alunos a construir um conhecimento que seja significativo (BRASIL, 2017a).

Dessa maneira, o professor deverá esclarecer que o sistema econômico que se estabeleceu como vigente gera, genuinamente, formas de desigualdades socioespaciais, o que inclui a pobreza, pois no Capitalismo os principais objetivos são a geração e o acúmulo da mais-valia (lucro), alicerçado sobre a exploração do trabalho (NETTO; BRAZ, 2006).

Para Saab (2018), não deve haver distanciamento entre o currículo ofertado e a realidade do dia a dia dos discentes, principalmente, para os estudantes pobres, pois, do contrário, seria sonegada a compreensão sobre e como ocorre a produção da pobreza, e também a sua inserção na sociedade, negligenciando suas culturas materiais e imateriais silenciando-as e excluindo-as dos currículos educacionais, os quais perfazem as trajetórias dos jovens estudantes do Ensino Médio.

Nesse sentido, a Geografia é uma ciência que permite o trabalho com o cotidiano e os elementos espaciais, entre eles o espaço urbano e todos os conceitos e temáticas intrínsecos a este conteúdo, de maneira que, enquanto disciplina, proporciona ferramentas para "[...] uma reflexão sobre a cidade, definida como um espaço de luta e contradições sociais, frente à desigualdade econômica e espacial, e 
que interfere na vida citadina, contribuindo para os vários problemas urbanos" (MANFIO; SEVERO; WOLLMANN, 2013, p. 02).

Segundo Oliveira (2008), o tema problemas urbanos é abordado no ensino de Geografia como paralelo a discussão sobre metropolização, com ênfase na dinâmica interna da cidade, nas condições de moradia, circulação e produção, déficit habitacional, paradoxalmente ao índice de domicílios vazios, a expansão urbana horizontal e vertical, o aumento da população superior à oferta de empregos, e, principalmente, as formas de pobreza e a falta de moradia, configurando o urbano como espaço para morar.

Nessa concepção, Oliveira (2008, p. 123) afirma que:

a cidade é também o lugar da vivência da maior parte da população mundial, de modo que o urbano, enquanto modo de vida, expressa a realidade da sociedade atual como um todo. Assim o ensino de Geografia tendo por base o eixo-temático cidade, ao mesmo tempo, possibilita a análise da sociedade e requer, ou leva a, uma reflexão sobre o lugar do aluno e do professor [...] requer a compreensão da cidade em que se vive, requer que os professores mobilizem conceitos que possibilitem analisar essa realidade, requer que o professor construa (crie) uma didatização sobre o conteúdo, em que o livro didático não se constituiu um empecilho, mas talvez um motivador.

Portanto, os problemas urbanos como a pobreza é um tema relevante, justamente por expressar a sociedade contemporânea, sendo uma temática atemporal, possibilitando trabalhar em sala de aula reflexões sobre os processos que levaram a edificação do cenário vivido nos dias atuais e trabalhar a criticidade dos discentes sobre a pobreza urbana enquanto problema urbano.

Diante do exposto, este trabalho tem por objetivo apresentar a análise feita em duas coleções de Livros Didáticos de Geografia do Ensino Médio, aprovados no Programa Nacional do Livro Didático (PNLD) de 2018, buscando identificar a ocorrência e forma de representação da pobreza nessas coleções. 
Para uma melhor abordagem e compreensão do tema, o presente trabalho está dividido em seis seções. Na seção inicial, o objetivo é apresentar uma discussão sobre o ensino da Geografia e sobre a questão da pobreza. Na segunda, se analisa como a temática Pobreza está disposta na área de Ciências Humanas da Base Nacional Comum Curricular (BNCC). Na terceira, aborda-se a importância Livro Didático de Geografia no processo de ensino e aprendizagem e do PNLD, na perspectiva do acesso ao conhecimento socialmente construído. A quarta, traz os procedimentos metodológicos que nortearam a pesquisa. A quinta, analisa como a temática Pobreza é apresentada em duas coleções aprovadas no PNLD 2018. Por fim, a última seção, traz às considerações finais.

\section{A BNCC E A LEITURA DA POBREZA NAS CIÊNCIAS HUMANAS}

Acompanhando a Reforma do Ensino Médio (Lei 13.415 de 2017), que prevê para o ensino médio uma carga horária de 1.400 horas por ano letivo; com apenas duas disciplinas obrigatórias, Português e Matemática, foi lançada a Base Nacional Comum Curricular (BNCC), que se trata de um referencial para nortear a construção dos currículos da educação básica.

A BNCC para o Ensino Médio prevê que as demais disciplinas serão ofertadas por área do conhecimento, sendo elas: Linguagem e suas Tecnologias, Matemática e suas Tecnologias, Ciências da Natureza e suas Tecnologias e Ciências Humanas e Sociais aplicadas, na qual está inserida a Geografia, História, Filosofia e Sociologia.

Não se trata mais de ensinar Geografia, História, Química, Biologia etc., com conteúdo que possui uma finalidade em si mesmo, mas sim, enquanto constituintes das grandes áreas do conhecimento.

Esse novo modelo de Ensino Médio,

propõe a ampliação e o aprofundamento das aprendizagens essenciais desenvolvidas até o $9^{\circ}$ ano do Ensino Fundamental, sempre orientada para uma educação ética. Entendendo-se ética como juízo de apreciação da conduta humana, necessária para o 
viver em sociedade, e em cujas bases destacam-se as ideias de justiça, solidariedade e livre-arbítrio, essa proposta tem como fundamento a compreensão e o reconhecimento das diferenças, o respeito aos direitos humanos e à interculturalidade, e o combate aos preconceitos (BRASIL, 2017a, p. 547).

O entendimento é de que a BNCC deve ser tratada no contexto geral da educação nacional, servindo a reflexão crítica acerca da desigualdade da sociedade brasileira e do papel da educação em sua superação e de como a Geografia, as Ciências Humanas e mais ainda a temática da Pobreza serão apresentadas e trabalhadas nesses moldes.

Nesse contexto, Couto (2017a, p. 07) afirma que

a BNCC deve servir ao propósito, sobretudo, de analisar e conhecer o Brasil de hoje e projetá-lo para o futuro. Considerando a atual e histórica realidade nacional, de grande concentração de riqueza e poder, cabe a BNCC servir ao propósito de mobilizar os professores, alunos e comunidade da escola pública brasileira para a reconstrução do Brasil, com um projeto contundente e claro de superação da acentuada desigualdade social entre os brasileiros, balizado pelas lutas das trabalhadoras/trabalhadores por direitos sociais e étnico-raciais, e baseado no estado laico, republicano, democrático e de direito à terra e à reforma agrária, à morada adequada, ao trabalho digno e devidamente remunerado, à saúde pública preventiva e curativa, à educação pública em todos os níveis, à cultura em diferentes expressões, ao respeito à diferença; todos entendidos como dever do estado e direito do cidadão.

Ao analisar o documento normativo da BNCC (BRASIL, 2017a) para o Ensino Médio, observa-se que a área do conhecimento Ciências Humanas e Sociais Aplicadas está organizada por competências e habilidades, e, em uma perspectiva de educação integral, prezando pela contextualização dos conceitos pertinentes a determinada área do conhecimento, com ênfase para atuação protagonista dos estudantes, de modo a fomentar temas para situá-los em seus contextos de vida. Na BNCC, valoriza- 
se, para a área de Ciências Humanas, os projetos de pesquisa ou de intervenção, sempre dialogando com os projetos de vida dos estudantes.

A Base Nacional para o Ensino Médio na área de Ciências Humanas e Sociais Aplicadas está estruturada em 6 competências e 31 habilidades a serem desenvolvidas dentro das referidas competências (BRASIL, 2017a). A competência 1 merece destaque, pois é de ordem epistemológica e geral da área, ela problematiza a natureza do conhecimento e as dicotomias, expondo que é competência da referida área

analisar processos políticos, econômicos, sociais, ambientais e culturais nos âmbitos local, regional, nacional e mundial em diferentes tempos, a partir de procedimentos epistemológicos e científicos, de modo a compreender e posicionar-se criticamente com relação a esses processos e às possíveis relações entre eles (BRASIL, 2017a, p. 559).

Nas demais competências também se pode identificar a presença de eixos temáticos pertinentes a Geografia, justamente pelo fato de se tratar de uma ciência holística e com um alto potencial para a interdisciplinaridade.

Nas competências presentes na BNCC para a área de Ciências Humanas no Ensino Médio, pode-se destacar duas que possibilitam uma ação mais direta para a leitura da Pobreza, uma vez que é mencionado o combate à desigualdade, o processo histórico e político na produção do espaço geográfico, expressando que é competência da área de Ciências Humanas

analisar a formação de territórios e fronteiras em diferentes tempos e espaços, mediante a compreensão dos processos sociais, políticos, econômicos e culturais geradores de conflito e negociação, desigualdade e igualdade, exclusão e inclusão e de situações que envolvam o exercício arbitrário do poder (BRASIL, 2017a, p. 558). 
Assim, essa competência possibilita que o professor possa estimular os alunos a avaliar a ocupação e as transformações do espaço, identificar os atores sociais atuantes na cidade e no campo, considerando suas influências em diferentes escalas e graus de alcance, bem como propiciar a compreensão das produções de diferentes territorialidades e as consequências que essa ação acarreta, como as desigualdade, a exclusão etc. (BRASIL, 2017a).

Uma outra competência, que também possibilita o trabalho docente voltado para a leitura e compressão da Pobreza, expressa que a área das Ciências Humanas no Ensino Médio deve possibilitar o reconhecimento e combate "[...] as diversas formas de desigualdade e violência, adotando princípios éticos, democráticos, inclusivos e solidários, e respeitando os Direitos Humanos" (BRASIL, 2017a, p. 558).

Desse modo, essa competência reforça a concepção e visão de mundo priorizando valores e atitudes de combate as injustiças e respeito à democracia e aos direitos humanos, em uma perspectiva de desenvolver o protagonismo dos estudantes, uma prioridade na BNCC.

As competências também abordam o desenvolvimento de habilidades críticas, reflexivas e autorais. Nesse sentido, a Geografia mostra-se como disciplina essencial nos currículos do Ensino Médio.

A BNCC ainda destaca categorias norteadoras para o ensino da área de Ciências Humanas e Sociais aplicadas e “[...] está organizada de modo a tematizar e problematizar, no Ensino Médio, algumas categorias dessa área, fundamentais à formação dos estudantes: tempo e espaço; territórios e fronteiras; indivíduo, natureza, sociedade, cultura e ética; e política e trabalho" (BRASIL, 2017a, p. 549).

Algumas dessas categorias estão carregadas de temas relacionados a Geografia e que em muitos pontos sugerem a leitura sobre a Pobreza, como por exemplo no tocante a categoria Política e Trabalho, que sugere a observação das

[...] transformações nas formas de participação dos trabalhadores nos diversos setores da produção, a precarização das relações de trabalho, as oscilações de taxas de emprego e 
desemprego, o uso do trabalho intermitente, a pulverização dos locais de trabalho e o aumento global da concentração de renda e da desigualdade social (BRASIL, 2017a, p. 557).

Assim, estudar Geografia é uma oportunidade para compreender o mundo em que vivemos, por isso, ela, enquanto disciplina está estruturada na BNCC com um caráter de conhecimento escolar e acadêmico sistematizado e progressivo, norteado pelo que esse documento chama de princípio do raciocínio geográfico.

Essa nova organização prevê que todo e qualquer objeto de conhecimento ou habilidade trabalhada no ensino de Geografia deve ser pensada a luz da teoria de soluções de problemas. Por essa razão, as questões geográficas devem sempre ser contextualizas com a realidade e com o cotidiano dos alunos, podendo ser incluídas nas aulas problemas como a Pobreza Urbana, apresentando ao estudante o porquê e de que forma este tema é geográfico.

\section{O LIVRO DIDÁTICO DE GEOGRAFIA}

O Livro Didático é um importante recurso para professores e alunos, sendo uma de suas funções apresentar os conteúdos de maneira sistematizada. As instituições públicas de ensino, através do Programa Nacional do Livro e do Material Didático $(P N L D)$, oferecem aos alunos o Livro Didático sem nenhum custo aos familiares, sendo a escolha desses materiais feita pelos professores das escolas a partir do Guia de Livros Didáticos, elaborado pelo Ministério da Educação (MEC) (BRASIL, 2017b).

Segundo RIBEIRO (2015), O PNLD, desde 1985, distribuiu milhões de Livros Didáticos para os alunos brasileiros. O programa surgiu a partir de Decreto ${ }^{\circ} 91.542$, de 19 de agosto de 1985, no entanto,

o Ensino Médio só veio participar do PNLD a partir de 2005, com distribuição parcial de livros de Português e Matemática para as regiões Norte e Nordeste. A partir de 2009 a distribuição torna-se nacional, e os alunos do Ensino Médio receberam 7 livros: 
Química e História, Matemática, Português e Biologia, além de Geografia e Física. De 2012 em diante, os alunos do Ensino Médio passaram a receber livros de língua estrangeira (Inglês e Espanhol) e livros de Filosofia e Sociologia (volumes únicos e consumíveis) [...] A distribuição do livro didático praticamente universalizou-se no Ensino Fundamental e Médio nas duas últimas décadas (RIBEIRO, 2015, p. 77, grifo nosso).

Nessa perspectiva, o Livro Didático tende a ser um dos recursos mais utilizados para o desenvolvimento dos processos de ensino-aprendizagem em sala de aula, principalmente em escolas públicas, que, muitas vezes, não dispõem de outras ferramentas e recursos. Lajolo (1996, p. 04) assinala que "para ser considerado didático, um livro precisa ser usado, de forma sistemática, no ensino-aprendizagem de um determinado objeto do conhecimento humano, geralmente já consolidado como disciplina escolar".

Atualmente, com os avanços técnico-científico-informacionais, o "livro didático apesar das críticas é um instrumento importante de apoio para os professores e alunos" (RIBEIRO, 2015, p. 92). Portanto, o Livro Didático tem um papel relevante no cotidiano escolar, sobretudo para os estudantes de famílias com menor poder aquisitivo, pois nesses lares o Livro Didático pode se configurar como a única referência de leitura, fonte de conhecimento e/ou material de estudo.

Segundo Tonini e Goulart (2017, p. 260),

o Livro Didático do século XXI, ainda que concorra com diferentes artefatos tecnológicos, continua sendo fundamental para o desenvolvimento do trabalho pedagógico na Escola Básica. Fonte de orientação do planejamento, o Livro Didático é referência para a maioria das ações pedagógicas, conforme se pode depreender das falas dos próprios professores ou mesmo da análise dos planos de estudo que circulam na maioria das escolas. Quando perguntados sobre a disposição/relevância das temáticas a serem tratadas nas salas de aula, muitas vezes, os professores se reportam as listas dispostas nos sumários dos livros. Daí tais instrumentos terem peso grandioso sobre o que e como se ensina/aprende na Escola Básica. 
Ribeiro (2015, p. 73) complementa afirmando que “o livro didático é um material escolar que teve e tem uma grande importância, mas que ainda sofre críticas dos meios acadêmicos", pois, os "[...] interesses econômicos das grandes editoras e até mesmo de autores contribuíram para estigmatizar o referido material" (RIBEIRO, 2015, p. 73). Além disso, o autor menciona que muitos professores, às vezes mal preparados ou com cargas horárias pesadas, utilizam o material como o condutor de todo processo de ensino-aprendizagem (RIBEIRO, 2015). Diante do exposto, é valido sinalizar que a qualidade do ensino, que perpassa também pelo uso adequado do livro didático, através da exploração das possibilidades pedagógicas desse recurso, está intimamente relacionada com a ação docente. Nesse sentido, vale frisar que essa atuação do professor está ligada diretamente a maiores investimentos, vontade política e planejamento voltados a construção de uma carreira sólida para o professor, com vistas a uma formação de qualidade e uma efetiva valorização profissional.

Diante de sua importância no processo de ensino-aprendizagem, é essencial que o professor também esteja preparado para fazer as análises e discussões sobre o Livro Didático, incluindo o de Geografia para o Ensino Médio; sobre como ele é produzido, como é escolhido, quais temáticas são abordadas, se este livro reflete a realidade do estudante etc., tendo, também, a nitidez de entender que a obra analisada, muitas vezes, reflete os “[...] interesses de grandes corporações, que se associam [...] [a] parte significativa do mercado editorial para perpetuar seus domínios" (VITIELLO, 2018, p. 117), bem como de que os livros didáticos, assim como a educação, não são imparciais, mas que, muitas vezes estão tomados de diversos interesses mercadológicos (VITIELLO, 2018).

Nesse contexto, pode-se afirmar que a importância do Livro Didático de Geografia na sala de aula só existe se o professor desenvolver com ele uma atividade produtiva e que esteja em constante transformação, refletindo sobre o espaço vivido dos discentes. Para tanto, "os professores devem possuir outras alternativas [...] 
[para] não apenas seguirem fielmente o livro didático, devem também orientar os alunos a buscar outros tipos de leitura" (RIBEIRO, 2015, p. 92).

Nesse sentido, Ribeiro (2015, p. 92), ressalta “[...] que a organização dos conteúdos e mesmo muitos textos, figuras, mapas até exercícios podem ser instrumentos facilitadores do processo de ensino-aprendizagem" e que "[...] um bom livro de Geografia deve seguir a perspectiva crítica e considerar vários elementos" (RIBEIRO, 2015, p. 77). Castrogiovanni e Goulart (2010, p. 134) ainda destacam a importância da fidedignidade das "informações contidas no livro, como conceitos específicos, dados, gráficos, tabelas, mapas etc., [que] devem ser as mais fiéis possíveis à realidade estudada" e que deve "fornecer [...] elementos que estimulem no aluno [...], a interpretação, reflexão e análise, uma visão crítica da realidade, levando-o a sentir-se como agente transformador da sociedade" (CASTROGIOVANNI; GOULART, 2010, p. 134).

Corroborando com essa discussão, Oliveira e Giordani (2017, p. 20) destaca que “a compreensão do espaço preconizada pela Geografia escolar deve incidir sobre a espacialidade dos sujeitos escolares, tornando-a problemática e tema de investigação".

Nos Livros Didáticos de Geografia do Ensino Médio a representação da Pobreza está relacionada a conteúdos e temáticas de caráter social e econômico, e, mais especificamente, a pobreza urbana está relacionada ao conteúdo de Urbanização e dentro da temática de problemas urbanos ou afins, pois

no tema ambiente urbano, indústria e modo de vida propõem trabalhar a relação indústria e ambiente urbano, para entender diversos aspectos relacionados a vida urbana. A partir deste tema abre-se um leque de possibilidades para estudar os diversos tipos de indústrias, os problemas ambientais decorrentes, as relações de trabalho, moradia, desemprego, políticas públicas urbanas etc. (ALMEIDA, 2018, p. 330, grifo do autor). 
Neste sentido, Cavalcanti (2006, p. 41) afirma que "a compreensão do tema cidade pelos alunos exige tratamento interdisciplinar, requer a formação de um sistema amplo de conceitos, a aquisição de muita informação e o desenvolvimento de uma série de capacidades e habilidades". Para tanto, Cavalcanti (2006), apresenta uma proposta de compreensão do conceito de Cidade a partir de três elementos principais: a aglomeração, a produção social e o cotidiano. Nesse contexto, a temática Pobreza está presente em todos os elementos, pois Cavalcanti (2006, p. 42) afirma que esses fatores nos levam a "pensar na cidade como um território, ou como um espaço que expressa uma infinidade deles".

Assim, pode-se dizer que "cidade é uma aglomeração de pessoas (habitantes, visitantes) e de objetos (edifícios, casas, ruas)" (CAVALCANTI, 2006, p.41), em torno dos quais a vida urbana se organiza. Essa organização torna a cidade um lugar complexo de produção social, “[...] no qual a identidade é vivida em fronteiras difusas, permeáveis, com muitos espaços de contato, de resistências e de exclusão, em que há manifestação de diferentes percepções, usos, culturas e aspirações de distintos grupos, em seus espaços públicos e privados" (CAVALCANTI, 2006, p. 42). Esse conjunto de relações caracterizam o cotidiano, marcado não só pelas relações diárias entre as pessoas, mas principalmente pela forma como se entende e se percebe a realidade.

É nesse aspecto que o ensino pode proporcionar o “[...] encontro/confronto da experiência imediata e cotidiana dos alunos com sua realidade e os conceitos científicos pertinentes" (CAVALCANTI 2006, p. 44), possibilitando ao professor discutir a Cidade em suas várias configurações, podendo assim abordar temas variados, dentre eles, a pobreza.

Almeida (2018, p. 332) complementa afirmando que

para este conteúdo o professor pode versar com os alunos sobre a cidade enquanto espaço contraditório, excludente e palco de conflitos, discutindo com os alunos como está sendo a administração de sua cidade, os investimentos em segurança, 
saúde, transporte, saneamento básico e educação. Ou seja, relacionar o conteúdo com o cotidiano do aluno, valorizando suas experiências do vivido, para formação de sujeito crítico, consciente e ativo.

Assim, construir o conceito de Cidade com os alunos, significa trabalhar o “[...] processo de consciência da diferença entre realidade objetiva e suas representações [...] [nesse sentido], o Livro Didático torna-se uma importante ferramenta para o professor em sala de aula", no entanto, "[...] deve-se considerar que o espaço urbano, cujo estudo é proposto ao aluno, nem sempre é o mesmo em que ele vive, e nem sempre é o que é o apresentado no Livro Didático" (VALLERIUS; SANTOS, 2017, p. 235).

Richter (2010, p. 215) ressalta que: “independente do tamanho da cidade, as diferenças sociais fazem parte do contexto urbano, principalmente por vivermos no sistema capitalista". Para o autor, "estas disparidades existentes entre uma região e outra precisam ser reconhecidas pelos alunos ao analisar a cidade de sua vivência, como também outras áreas urbanas" (RICHTER, 2010, p. 215).

Assim, as atuais mudanças na concepção do que e como ensinar, projetam a construção de um ensino de Geografia mais próximo de "questões latentes da atualidade, como a compreensão de problemas urbanos que afetam a sua própria cidade, da integração do espaço local com o processo de globalização, suas vantagens e desvantagens" (RICHTER, 2010, p. 115). Nesses moldes, a representação da Pobreza deve ser contemplada por conteúdos presentes no Livro Didático e trabalhados na Geografia com vistas para uma formação cidadã.

Ladeira e Leão (2018, p. 200), afirmam que "grande parte dos noticiários aborda questões relacionadas à Geografia [...]", por isso, é importante que na Geografia, enquanto disciplina escolar, aborde as fontes de comunicação em massa e suas referências sobre a temática pobreza, que podem estar presentes no Livro Didático de Geografia em formato de reportagem, notícia ou relacionada a dados oficiais em formato de gráficos/tabelas. 
Vale ressaltar que a utilização da comunicação em massa, apesar de ajudar a construir um conhecimento calcado na realidade vivenciada e/ou observada pelo estudante, deve partir de uma compreensão de que, apesar de serem formas de divulgação de conhecimentos e fatos inerentes a sociedade contemporânea, são passiveis de uma leitura crítica, não podendo ser encaradas como verdades absolutas.

Nessa perspectiva, Deon (2018), afirma que a qualidade dos Livros Didáticos e dos conteúdos nele expressos é fundamental para a cidadania no processo educativo escolar, pois

[...] o Livro Didático é um material que oportuniza a leitura e a informação de temas, que além de serem de conteúdos próprios da disciplina escolar, são questões da realidade e do mundo atual [...] se esses conteúdos forem trabalhos de modo a que o estudante reconheça que está aprendendo teórica e conceitualmente e é significativo para a sua vida, a Geografia estará cumprindo o seu papel social de formação para a cidadania (DEON, 2018, p. 44-45).

Assim, com o suporte do Livro Didático de Geografia, ao abordar a temática Pobreza o professor e o aluno terão um apoio; materializado em textos, conceitos, contextos, imagens, charges, reportagens, dados, infográficos, entre outros formatos, que auxiliará na explanação, na discussão, no questionamento e na construção do conhecimento sobre o espaço geográfico socialmente produzido, já que, segundo Ribeiro, (2015 p. 92), “[...] a organização dos conteúdos e mesmo muitos textos, figuras, mapas até exercícios podem ser instrumentos facilitadores do processo de ensino-aprendizagem".

Fomentar um olhar mais atento dos estudantes frente a temática estudada, capacita os mesmos a realizarem interpretações da Pobreza enquanto fenômeno presente no cotidiano pois, muitas vezes, ela, a pobreza, ocorre próximo deles, mas é banalizada e/ou naturalizada, o que acaba fazendo com que seja invisibilizada no dia a dia dos discentes. Desse modo, o Livro Didático de Geografia do Ensino Médio tem 
também a função de integrar o conhecimento empírico com os conteúdos e elementos necessários para realizar a leitura do espaço geográfico de forma holística, considerando todos os atores e interesses envolvidos.

\section{METODOLOGIA}

Esta pesquisa é um estudo de abordagem qualitativa que tem por objetivo discutir e analisar a representação da Pobreza no Livro Didático de Geografia do Ensino Médio.

De acordo com Dalfovo, Lana e Silveira (2008, p. 9) a “pesquisa qualitativa é aquela que trabalha predominantemente com dados qualitativos [...]". Tozoni-Reis (2007) e Knechtel (2014), complementam afirmando que na pesquisa qualitativa, o pesquisador não atua como mero expectador, é o principal instrumento, sendo, portanto, protagonista da pesquisa.

Para construção do presente trabalho foi realizado primeiramente a revisão da literatura, com o objetivo de aprofundar o tema a ser trabalhado. Segundo Moreira e Caleffe (2006, p. 27), “[...] a revisão da literatura é parte central de qualquer estudo, pois ela demonstra a familiaridade do pesquisador com a literatura contemporânea e a sua capacidade de avaliar criticamente as pesquisas já realizadas". Os autores ainda complementam afirmando que "[...] uma boa revisão de literatura ajuda o professor/pesquisador a contextualizar o seu problema de pesquisa em um modelo teórico mais amplo [...]. Portanto, o professor/pesquisador deve ser capaz de identificar na literatura temas comuns e relacioná-los com o seu problema" (MOREIRA; CALEFFE, 2006, p. 27). A condução da revisão da literatura seguiu o modelo de Cooper (1984 apud MOREIRA; CALEFFE, 2006), que organiza essa fase da pesquisa em: 1) formulação do problema; 2) seleção dos textos; 3) avaliação dos textos; 4) análise e interpretação e, por fim, 5) redação.

A investigação considerou o parecer dos Guias de Livros Didáticos Ensino Médio referente ao PNLD 2018, baseou-se na análise de duas coleções de Livros Didáticos 
para o Ensino Médio, sendo elas: 1- \#Contato Geografia, dos autores Rogério Martinez e Wanessa Garcia, da editora Quinteto, com ano de publicação 2016, composta de 3 volumes (Figura 1); 2- Geografia no Cotidiano, dos autores Dadá Martins, Francisco Bigotto e Marcio Vitiello, da editora Base Editorial, com ano de publicação 2016, composta de 3 volumes (Figura 2). As coleções foram aprovadas pelo PNLD de 2018, estando em uso nas escolas até o ano letivo de 2020.

Figura 1 - Coleção \#contatoGeografia

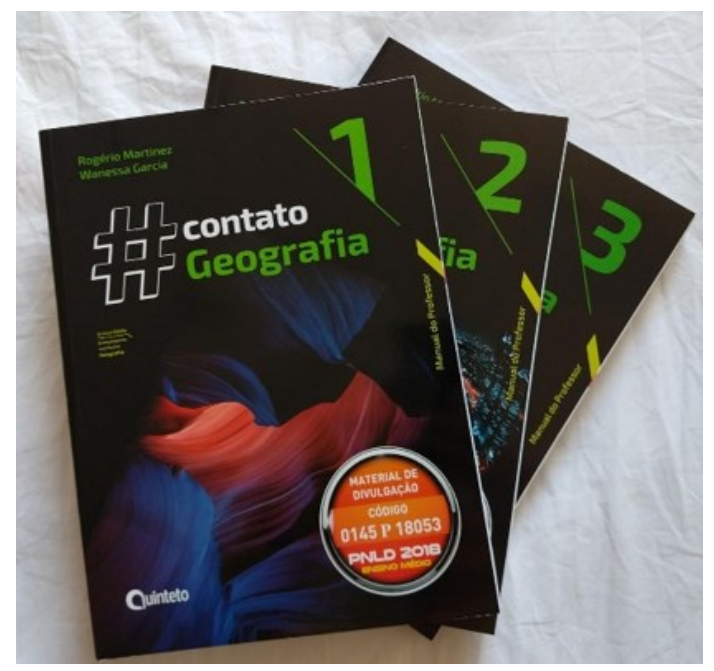

Fonte: MARTINEZ, GARCIA, 2016.

Figura 2 - Coleção Geografia no cotidiano

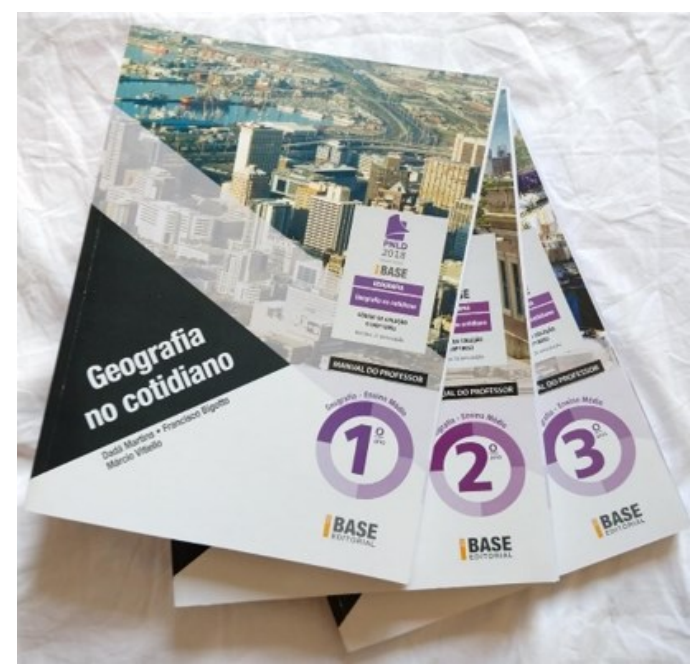

Fonte: MARTINS; BIGOTTO, VITIELLO, 2016. 
O critério para a escolha dos livros analisados foi serem livros aprovados pelo Programa Nacional do Livro Didático (PNLD) de 2018, além de estar em uso nas escolas públicas brasileiras.

A Análise se baseou em três passos. O primeiro foi a leitura do Guia PNLD, disponível para download no site do Fundo Nacional de Educação, cujas resenhas sobre os livros indicam como os conteúdos e temáticas estão sendo abordados. O segundo foi a leitura do sumário dos livros, nos quais buscou-se pela representação da temática Pobreza em suas páginas, para assim analisar e comparar em quais conteúdos, contextos e perspectivas a temática estaria inserida. Por fim, a leitura e análise de como a temática Pobreza estava representada nos livros (textos do próprio livro, textos complementares, imagens, músicas mapas e gráficos).

No processo inicial de seleção e escolha das obras foi possível perceber que os volumes 1, geralmente utilizados no $1^{\circ}$ ano do Ensino Médio, não traziam a referida temática como conteúdo a ser estudado, estando o trato com a temática Pobreza presente apenas nos volumes 2, da coleção \#Contato Geografia e no volume 3 da coleção Geografia no Cotidiano, utilizados, geralmente, no $2^{\circ}$ e $3^{\circ}$ ano do Ensino Médio.

\section{ANÁLISE DOS LIVROS DIDÁTICOS DE GEOGRAFIA DO ENSINO MÉDIO}

\subsection{Em análise o livro \#Contato Geografia}

O primeiro livro analisado foi o \#Contato Geografia, volume 2, de Rogério Martinez e Wanessa Garcia, primeira edição, da Quinteto Editorial, e publicado em 2016 (Figura 3).

Esse Livro Didático foi aprovado no PNLD de 2018 e segundo o Guia do PNLD no referido livro

os conteúdos versam sobre a relação natureza, sociedade e espaço geográfico, conforme a seguinte disposição: Natureza, sociedade e espaço geográfico; Indústria e espaço geográfico; 
Fontes de energia; População Mundial; População Brasileira; Urbanização; Urbanização e industrialização no Brasil; A urbanização brasileira e seus problemas; A agricultura no mundo; e O espaço agrário brasileiro (BRASIL, 2017c, p. 68).

Figura 3 - Capa volume 2 da coleção \#contatoGeografia

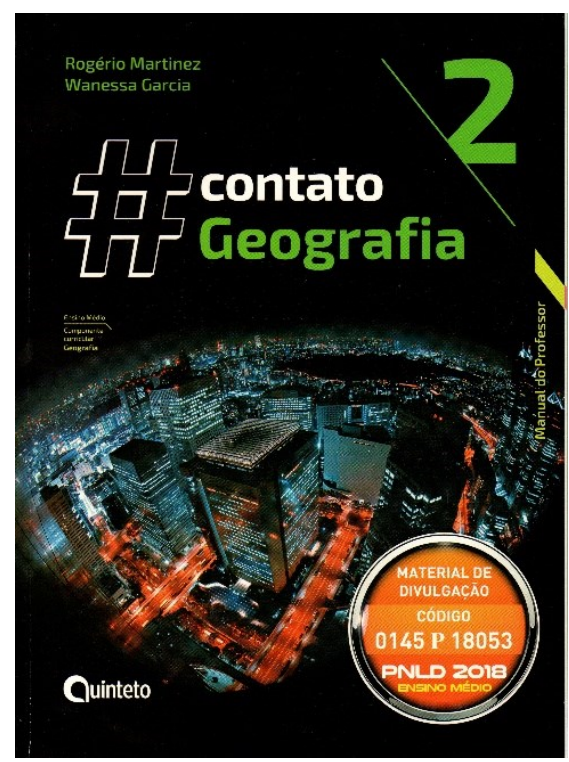

Fonte: MARTINEZ; GARCIA, 2016.

A temática Pobreza está representada na coleção no volume 2 , nos assuntos das unidades 6 Urbanização e 8 Urbanização Brasileira e seus Problemas (Figura 4).

Figura 4 - Parte do sumário do volume 2 que traz assuntos que contemplam a pobreza

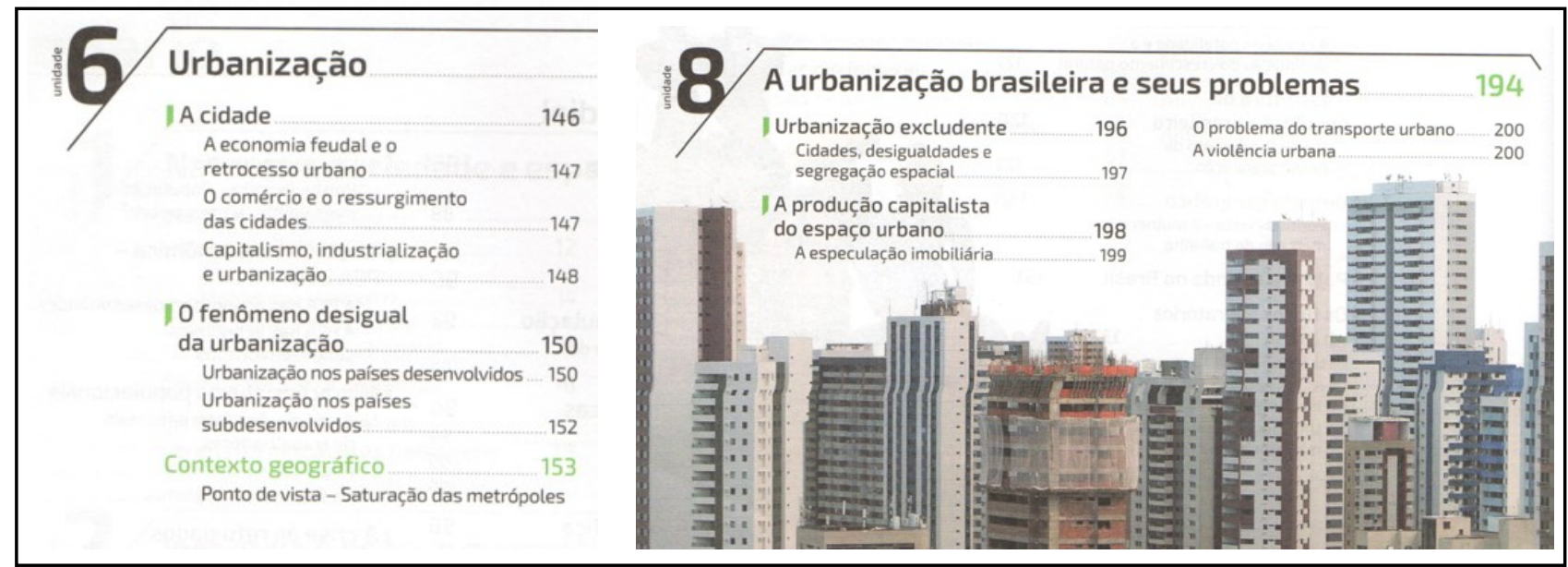

Fonte: MARTINEZ; GARCIA, 2016 
Na página 131, retrata-se que a Pobreza é causada principalmente pelo desemprego, o que acarreta na ampliação da economia informal e do trabalho infantil, caracterizando-se pela concentração de renda, de maneira que, essa desigualdade gera divergência de acesso a bens e serviços, o que inclui, alimentação, saúde, educação, saneamento, vestuário e moradia digna.

Neste livro, nota-se o Brasil como protagonista, essa característica é válida dentro da perspectiva da presente pesquisa que prioriza a concepção de um ensino de Geografia sob o viés da educação cidadã. Nesse sentido, ainda na página 131, são apresentados dados sobre a Pobreza no formato de gráficos (Figura 5); sobre o rendimento nacional, com enfoque para a disparidade entre ricos e pobres referente ao ano de 2013 e sobre o percentual da população brasileira abaixo da linha de pobreza extrema, compreendendo o intervalo entre os anos de 1981 a 2013.

Figura 5 - Gráficos sobre pobreza e renda no Brasil

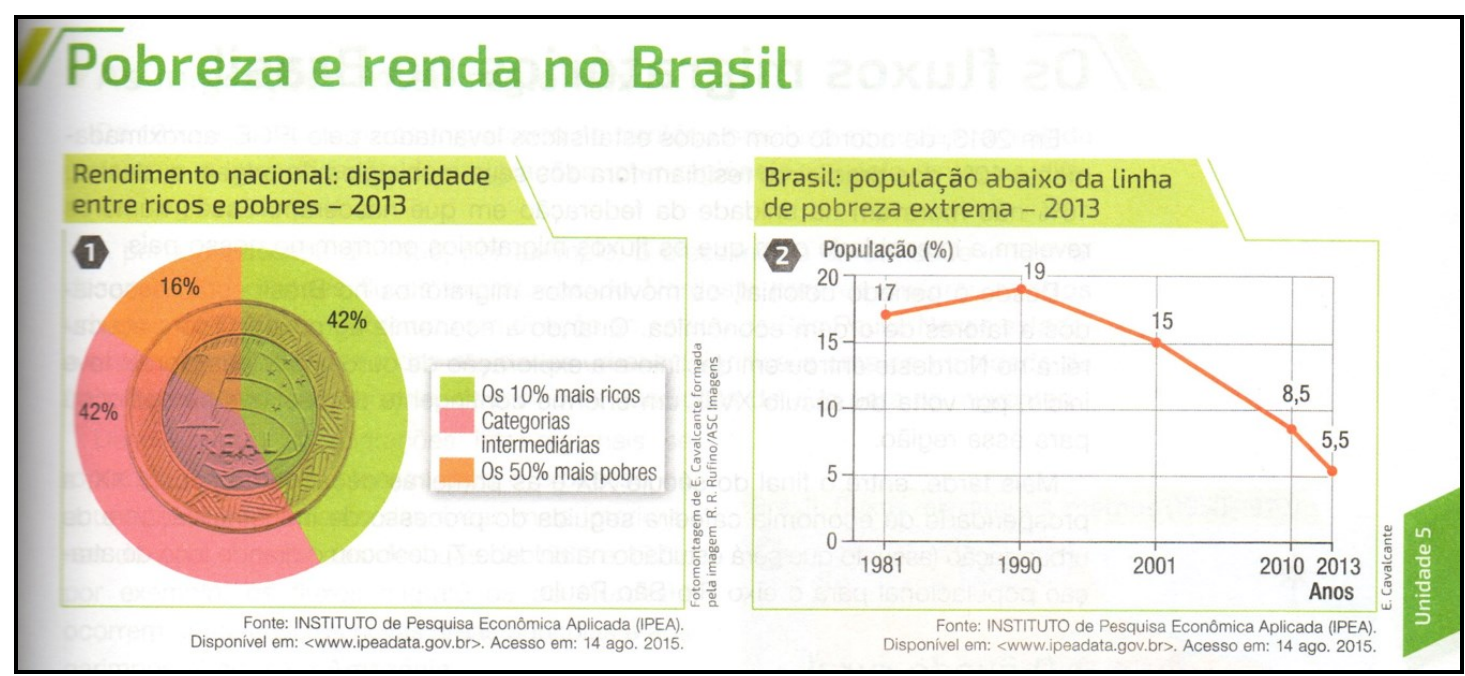

Fonte: MARTINEZ; GARCIA, 2016, p. 131

Vale destacar que ao final da página 131, é explanado sobre o conceito de IDH e é sucintamente apresentada a situação do desenvolvimento humano no Brasil. É salientado ainda, que embora o Brasil tenha êxito no desenvolvimento econômico e no PIB, apresentou um IDH de 0,755 em 2015, muito próximo ao dos países vizinhos como Venezuela e Peru. Logo após a explanação, há um questionamento reflexivo, “crescimento econômico pode ser considerado desenvolvimento social?", que permite 
um maior aprofundamento na temática, a fim de discutir sobre a pobreza no Brasil; no estado, no município e no bairro do estudante. Mesmo porque, a Pobreza não deve ser vista apenas como um problema quantitativo, numérico ou exclusivamente de renda, mas como um fenômeno qualitativo e, portanto, estrutural (SANTOS, 2009).

Assim, a forma como a coleção analisada apresenta o conteúdo coaduna com a acepção de Couto (2017b, p. 197), que ressalta que

cabe a Geografia descrever o mundo para explicá-lo. Para isso, a descrição deve ser combinada com a explicação, precedida e acompanhada da pergunta que a orienta; ou seja, primeiro pergunta e problematiza e depois descreve; o problema a ser pensado e respondido conduz a descrição.

Na sequência, na página 155, para retratar a pobreza no contexto da América Latina, é apresentada uma foto de moradias precárias em Lima, no Peru, em 2015 (Figura 6). A imagem é utilizada para refletir sobre a discussão edificada no texto acerca do crescimento desordenado e de como ele acarreta ocupações em situação de penúria e sem infraestrutura, a imagem elucida sobre como as formas de pobreza são semelhantes no mundo globalizado.

Figura 6 - Moradias precárias em Lima, Peru, em 2015

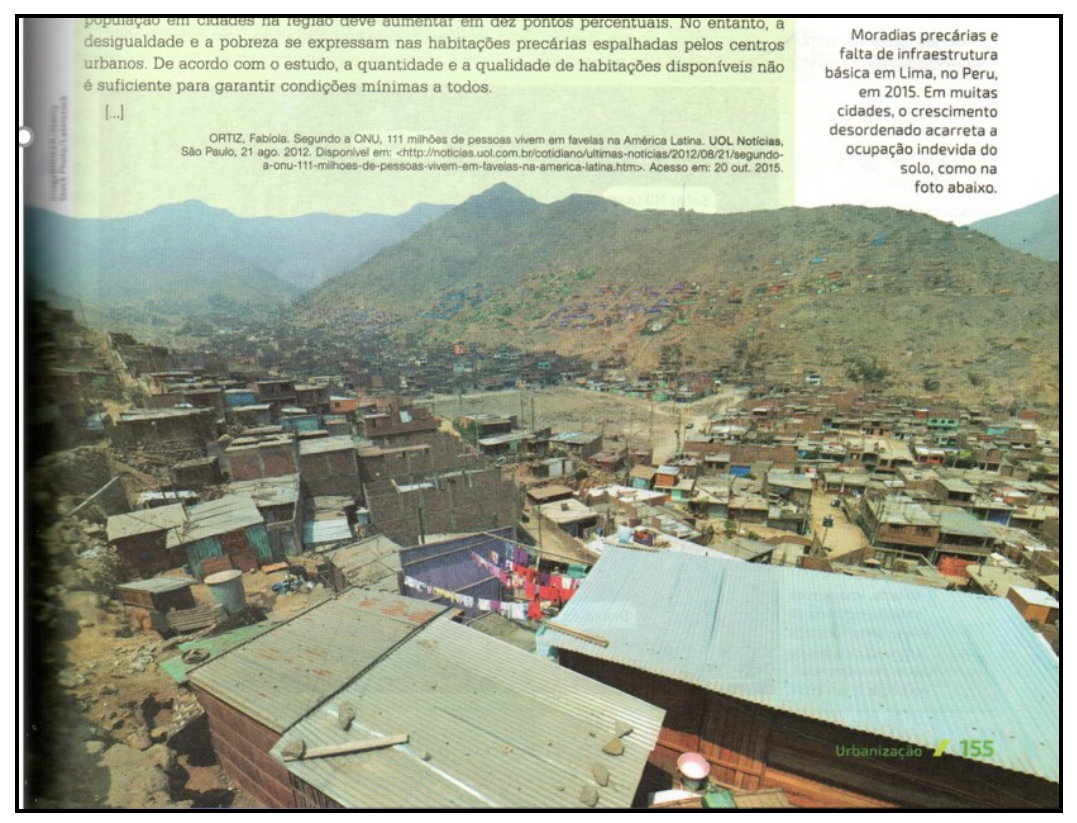

Fonte: MARTINEZ; GARCIA, 2016, p. 155 
Nas páginas 194 e 195 (Figura 7) há uma unidade dedicada aos problemas urbanos. Essa unidade começa tratando sobre a desigualdade econômica estampada em suas páginas iniciais. A imagem é muito comum de ser encontrada quando o assunto é concentração de renda, urbanização desigual e pobreza como problema urbano. Trata-se de uma fotografia da vista da Favela Paraisópolis e do bairro do Morumbi (2013) e expressa a desigualdade na cidade de São Paulo.

Figura 7 - Unidade 8, com foto da vista da Favela de Paraisópolis e do Bairro Morumbi (SP)
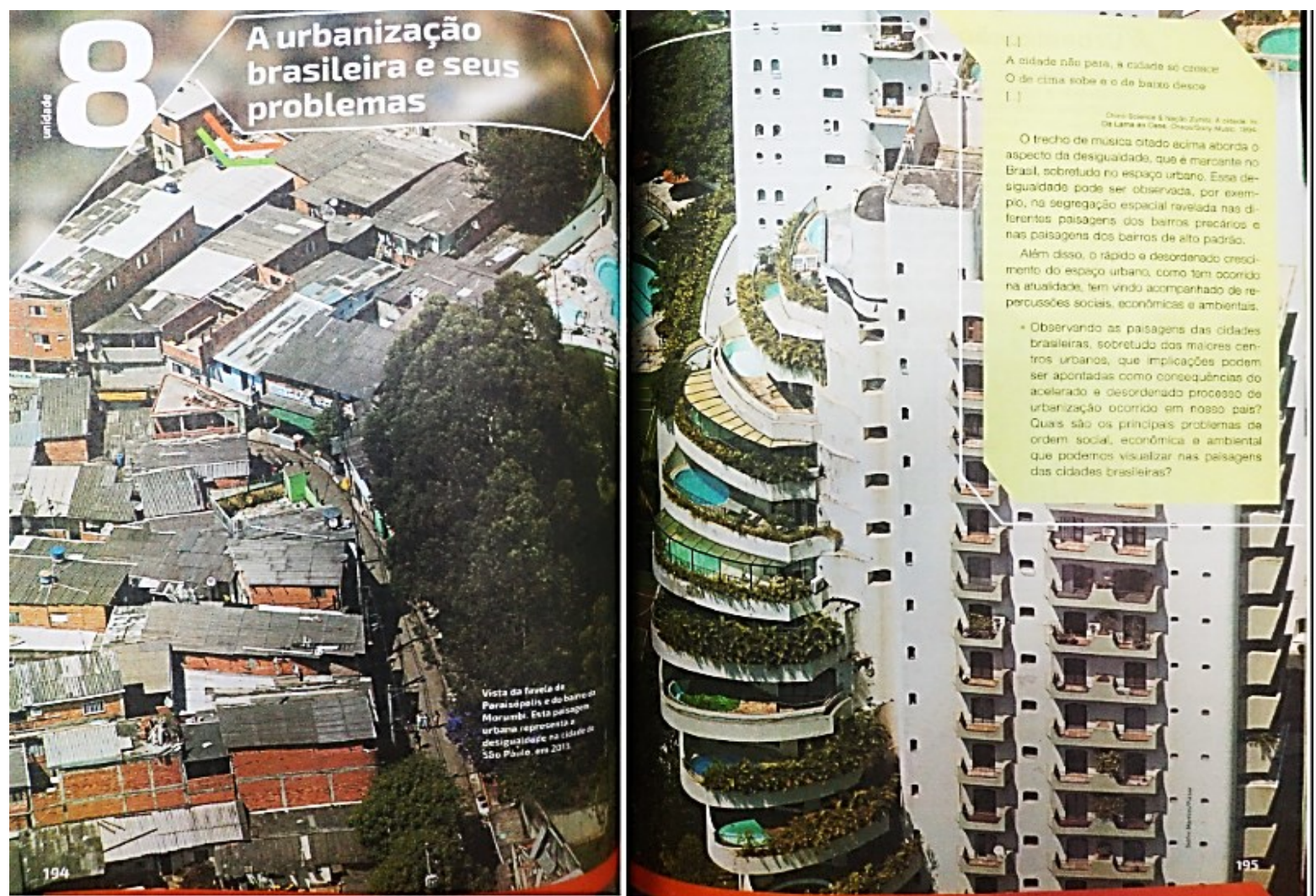

Fonte: MARTINEZ; GARCIA, 2016, p. 194-195

Esta imagem pode ser considerada clichê por ser recorrente quando o assunto é desigualdade socioeconômica, nesse sentido, de acordo com Firmino e Martins (2017), por meio de imagens, o clichê presente nelas enquadra as significações de certo modo, trazendo consigo uma maneira uniformizada de pensar as produções imagéticas contidas nos Livros Didáticos. Portanto, o perigo de dar uma grande visibilidade a uma imagem clichê como a da Figura 8 é de limitar a construção da ideia do que vem a ser a desigualdade socioeconômica existente no Brasil, uma vez que, 
em outras regiões, o estudante pode não observar uma paisagem como a que pode ser vista nas favelas do Rio de Janeiro e de São Paulo.

Firmino e Martins (2017, p. 105) afirmam que "a importância em problematizar as imagens que compõem os Livros Didáticos de Geografia se dá no sentido de que a Geografia necessita ser também construída e alargada pelo olhar". Portanto, diversificar a forma como os temas são retratados auxilia na compreensão e na ampliação da análise da realidade.

Mais adiante, na página 196, é explanado sobre Urbanização e seu caráter excludente na perspectiva de que é uma das características marcante do subdesenvolvimento. Nessa abordagem é realizada uma contextualização histórica para justificar o alto desemprego que acomete a população brasileira. Assim, é pontuado que o setor industrial brasileiro não foi capaz de absorver a mão de obra que migrou do campo para os centros urbanos, fazendo com que os trabalhadores desempregados ingressassem no setor terciário, exercendo atividades informais ou com baixa remuneração e sem vínculo empregatício.

Nesse sentido, é abordado que o grande número de subempregados e trabalhadores informais somados ao número de desempregados constituem o exército industrial de reserva, termo cunhado por Karl Marx e apresentado em uma caixa de texto à parte da página 196. O texto, da mesma página, enfatiza ainda que esse contexto de falta de emprego, emprego mal remunerado e/ou em condições insalubres, sem nenhuma proteção social, associado a falta de planejamento urbano para abrigar esse contingente populacional, explica em parte o aumento da pobreza e miséria visível nas cidades, sobretudo nos centros urbanos do país (MARTINEZ; GARCIA, 2016). Não obstante, poderia haver dados oficiais sobre o desemprego no Brasil em formato de gráficos ou no corpo do texto a fim de tornar a discussão mais significativa.

Na página seguinte, 197, o livro destaca uma relevante citação de Hermínia Maricato, da obra Habitação e Cidade (1997), e uma fotografia que mostra uma favela no primeiro plano e vários prédios de luxo ao fundo em Salvador, Bahia, em 2015 
(Figura 8). A citação se refere a desigualdade e segregação espacial, na qual a autora elucida que o acesso a moradia está relacionado aos interesses do mercado imobiliário, que diz respeito a localização da moradia e a infraestrutura que ela oferece. A autora ainda assinala que até mesmo a segurança policial é feita de maneira distinta na periferia.

Figura 8 - Citação da obra Habitação e Cidade e imagem que retrata segregação espacial em Salvador (BA)

Quando alguém compra uma casa, está comprando também as oportunidades de acesso aos serviços coletivos, equipamentos e infraestrutura. Está comprando a localização da moradia, além do imóvel propriamente dito. Edifícios residenciais de mesma área, mesmos materiais de construção, mesmos acabamentos têm preços diferentes, dependendo de onde se situam: num bairro com transporte abundante, praças, escolas, arborização, iluminação, etc., ou na periferia, que reúne carências múltiplas e onde o número de homicídios é mais alto, pois o serviço da polícia se faz de forma distinta na cidade, priorizando a defesa dos patrimônios pessoais. Até mesmo o tipo de vizinhança interfere na valorização de imóveis e terrenos.

$[\ldots]$

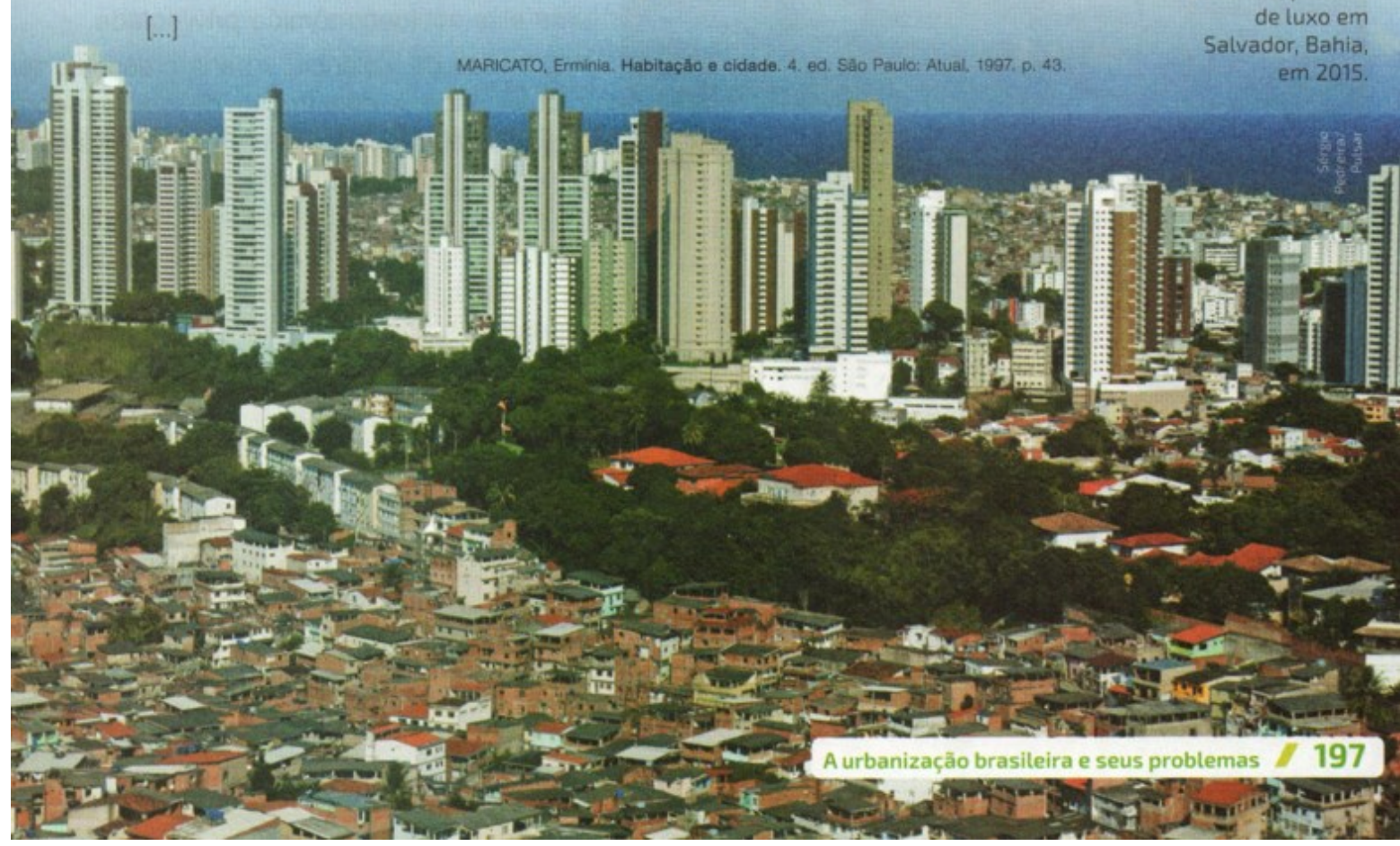

Fonte: MARTINEZ; GARCIA, 2016, p. 197

Finalizando a análise do volume 2 da coleção \#Contato Geografia, na página 198, identifica-se a representação da temática pobreza dentro do contexto da produção capitalista do espaço urbano, de maneira que, as grandes aglomerações de 
submoradias são apontadas enquanto um dos problemas mais graves no meio urbano.

\subsection{Em análise o livro Geografia no Cotidiano}

O segundo e último livro analisado neste trabalho é o volume 3 da coleção Geografia no Cotidiano de Dadá Martins, Francisco Bigotto e Marcio Vitiello, um livro da editora Base Editorial e publicado no ano de 2016 (Figura 9).

Figura 9 - Capa do volume 3 da coleção geografia no cotidiano

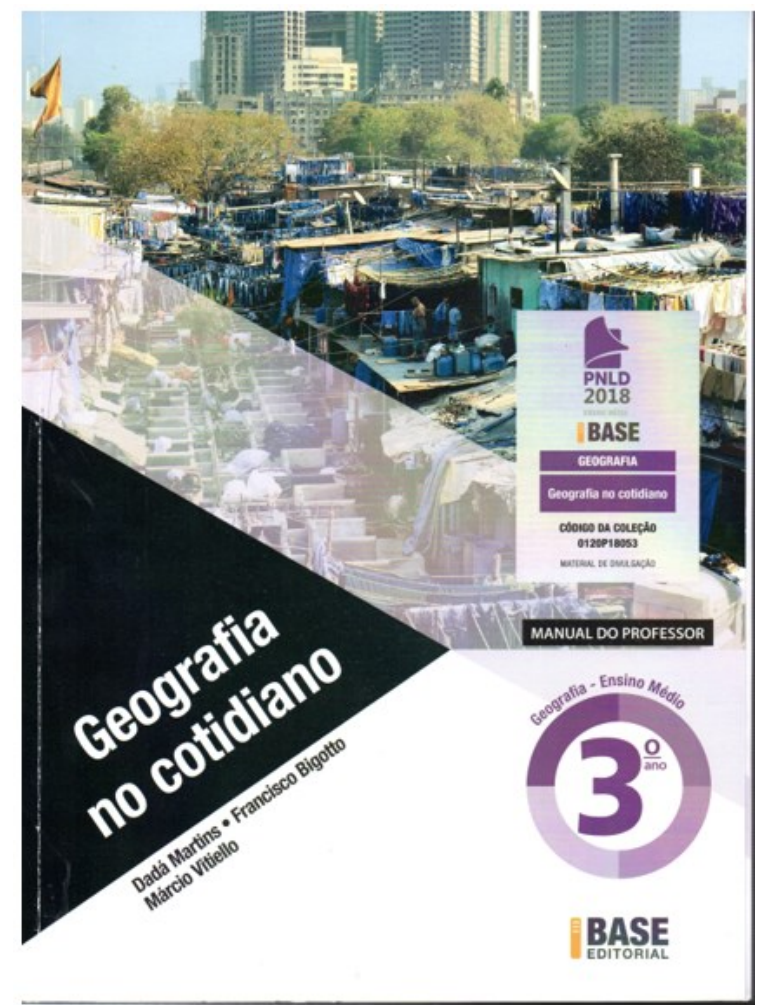

Fonte: MARTINS; BIGOTTO, VITIELLO, 2016

Segundo o Guia do PNLD, no referido livro

as temáticas geográficas são analisadas em escala global, recorrendo-se à Geografia Regional. Os capítulos da primeira unidade versam sobre a construção, o domínio, as condições socioeconômicas do espaço geográfico mundial em relação à industrialização, à globalização e à Nova Ordem Mundial. A segunda unidade trata das regiões socioeconômicas mundiais que destacam as características gerais dos Países do Norte (América Anglo-Saxônica, Nações desenvolvidas do Pacífico e Europa), dos Países do Sul (África, América Latina e Ásia). Aborda, 
ainda, o grupo de países não alinhados, o G-77 e os países de economias emergentes, inclusive os BRICS. Na terceira unidade, questões do mundo contemporâneo são discutidas nos capítulos que apresentam temáticas voltadas para os estudos da população e dos movimentos migratórios (BRASIL, 2017c, p. 51).

Embora tenha como título "Geografia no Cotidiano" a coleção deixa a desejar no que se refere a temática investigada, de maneira que, só foi identificado a presença do tema Pobreza em apenas duas páginas, que compreendem o capítulo 3 As Condições Socioeconômicas e a Organização do espaço Geográfico Mundial (Figura 10). Mesmo assim, em páginas distantes uma da outra, páginas 50 e 68, o que implica que as informações acerca da temática não se complementam na sequência adotada no livro, estando dispostas, literalmente, no início e no final do capítulo 3.

Figura 10 - Sumário capítulo 3 do volume 3 da coleção Geografia no Cotidiano

\begin{tabular}{l}
\hline \hline Capítulo 3 \\
As condições socioeconômicas \\
e a organização do espaço \\
geográfico mundial................................. 50 \\
Indicadores socioeconômicos ................................ 51 \\
Crescimento econômico $\times$ desenvolvimento \\
humano: contradições do capitalismo ...................... 52 \\
Índice de Desenvolvimento Humano (IDH) ................. 55 \\
IDH e a organização do \\
espaço geográfico mundial..................................... 65 \\
Síntese e compreensão .........................................67
\end{tabular}

Fonte: MARTINS; BIGOTTO, VITIELLO, 2016

O capítulo 3 se inicia com questionamentos que solicitam uma análise e interpretação das imagens apresentadas (Figura11). Segundo Couto (2017b, p. 210), “os Livros Didáticos que se iniciam com perguntas ou proposição de atividades para os alunos, visando sondar seus conhecimentos prévios, interesses e expectativas, estão inspirados na pedagogia nova". 
Figura 11 - Representação da pobreza, imagens e questões

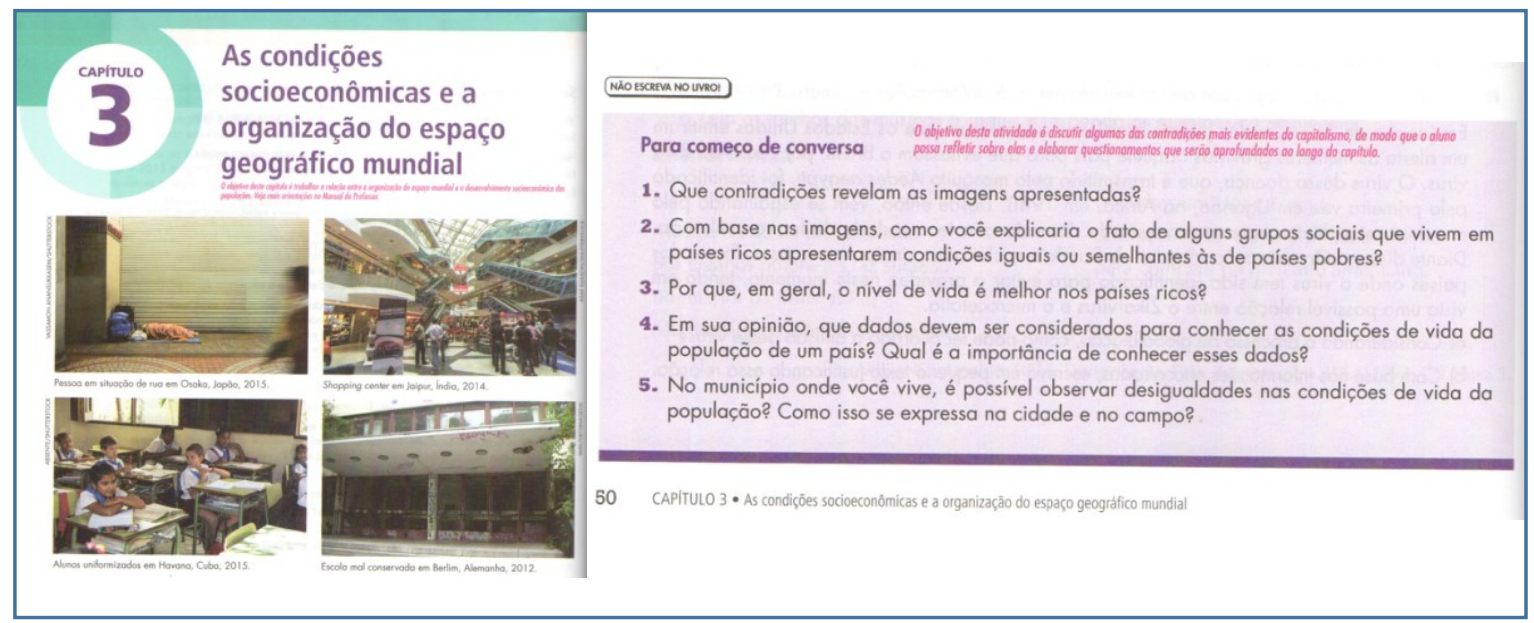

Fonte: MARTINS; BIGOTTO, VITIELLO, 2016 p. 50

Apesar de uma postura analítica e reflexiva sobre a realidade mostrada nas imagens, a terceira pergunta soa um tanto quanto determinista e induz o estudante a concordar com a pergunta/afirmação: “Por que em geral, o nível de vida é melhor nos países ricos?". Quanto as demais perguntas exigem do discente um conhecimento prévio, pois as informações contidas no livro são insuficientes. Contudo, a quinta pergunta: “No município onde você vive, é possível observar desigualdades nas condições de vida da população? Como isso se expressa na cidade e no campo?", é válida na perspectiva de edificar uma educação cidadã, que este trabalho defende, pois questiona sobre a realidade do estudante e solicita que ele explique a distinção das formas de expressão das desigualdades tanto na cidade como no campo.

Na página 68 do volume 3 se encontrar uma questão composta por um texto de Bertold Brecht (1898-1956), A exceção e a regra, e por quadrinhos (Figura 12), na qual se identifica a temática Pobreza.

Ambos retratam a desigualdade socioeconômica, sendo que nos quadrinhos é expresso o ápice da desigualdade socioeconômica e da concentração de renda, de modo a ressaltar a realidade da situação de rua de uma família, na qual mostra dois personagens, pai e filho. Na sequência, há uma única atividade, que solicita aos alunos a elaboração de um texto dissertativo sobre a temática representada no texto e nos quadrinhos. A questão solicita que os estudantes se apoiem no conteúdo 
apresentado no capítulo 3, a fim de realizar uma argumentação coerente e que consiga responder a questão central sobre se há relação entre o texto e os quadrinhos. É importante utilizar outros formatos para além da descrição em textos, pois, "a descrição da realidade pelo método descritivo, normalmente utilizado pelos Livros Didáticos, não é a opção que leva o aluno a compreensão crítica do mundo e de sua posição nele (COUTO, 2017b, p. 196).

Figura 12 - Questão 2 que se refere a pobreza

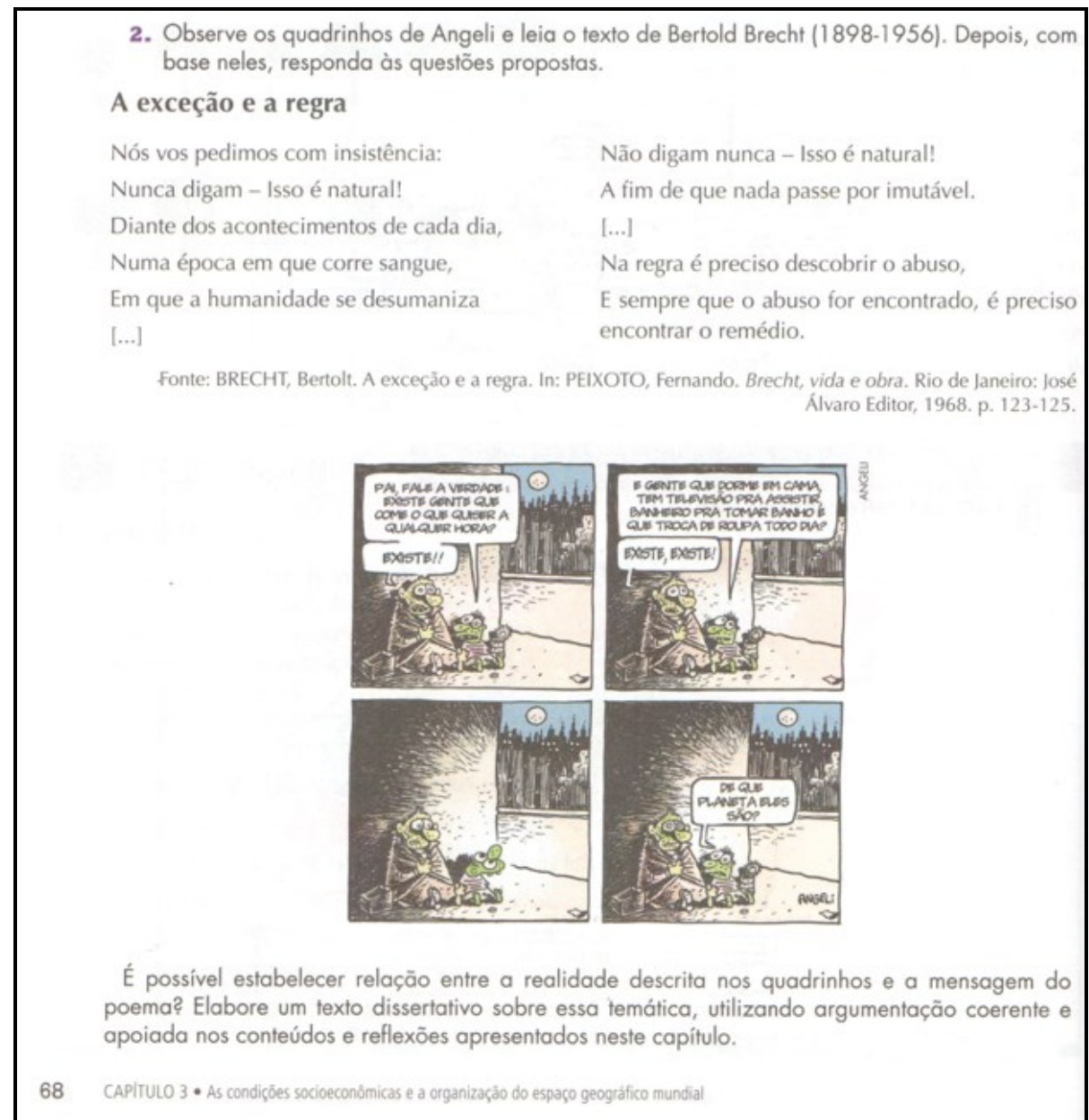

Fonte: MARTINS; BIGOTTO, VITIELLO, 2016, p. 68

Nesse sentido, espera-se que o estudante responda considerando o conhecimento construído em sala de aula a partir do que está representado no Livro Didático de Geografia sobre a desigualdade socioeconômica, no entanto, como o livro não dispõe de maiores explicações e contextualizações, o professor não deve tê-lo como uma única fonte, buscando, assim, outras fontes para além do Livro Didático e que valorize o conhecimento prévio e empírico do estudante. 


\section{CONSIDERAÇÕES FINAIS}

O Livro Didático é um recurso importante para a construção do saber dentro e fora da sala de aula e mesmo com o advento da era da informação/digital ainda se mostra um importante recurso, principalmente, quando se considera a escassez de outros aportes nas escolas públicas.

Por essa razão, o professor tem a responsabilidade de realizar uma mediação crítica sobre os conteúdos que o livro apresenta, pois muitas vezes traz somente apontamentos superficiais sobre temáticas importantes para uma formação cidadãcrítica, como no caso dos livros aqui analisados, que embora abordem a temática pobreza, o faz de modo sucinto, sonegando a complexidade do fenômeno, naturalizando a pobreza ou fazendo parecer ser uma realidade distante do educando.

Nesse sentido, a Geografia escolar deve preocupar-se em observar, identificar e discutir problemas percebidos na sociedade a fim de representá-los nos Livros Didáticos, para assim construir um conhecimento geográfico questionador da realidade e, portanto, significativo, objetivando um ensino de Geografia que esteja vinculado ao cotidiano observado e vivenciado pelos alunos.

O documento normativo da BNCC para o Ensino Médio, prevê a Geografia dentro da área de Ciências Humanas e Sociais Aplicadas, de maneira que, identifica-se a presença de eixos temáticos pertinentes a Geografia em todas as competências apresentadas e mais ainda, constata-se competências que possibilitam o trabalho docente voltado para a leitura e compreensão da Pobreza dentro de uma perspectiva de educação para a formação cidadã.

No que concerne, especificamente, as obras analisadas, foi identificada a presença da temática Pobreza, de modo que, condiz com os embasamentos proporcionados pelo referencial deste trabalho. Observou-se que a temática é abordada nos livros analisados de maneira distinta, pois, o livro \#Contato Geografia contempla o tema em assuntos dispostos em duas unidades do livro, isso favorece um maior aprofundamento a respeito do conteúdo, abordando a temática tendo o 
Brasil como protagonista e apresenta imagens que auxiliam o estudante a identificar similaridades com o espaço urbano conhecido e habitado. O livro analisado também apresenta dados oficiais que retratam a desigualdade econômica no país, o que fomenta a discussão e a busca pelo conhecimento.

Já o livro Geografia no cotidiano, dispõe apenas de um capítulo que trata sobre a temática, no qual apenas duas páginas abordam o tema, tornando a discussão sobre a temática sucinta. Não obstante, o livro traz à tona a pobreza extrema, representando a situação de rua em uma imagem e quadrinhos, que, associados aos questionamentos solicitados no livro, oportunizam a construção do conhecimento crítico e significativo.

Por fim, evidencia-se a importância da discussão e estudos sobre os Livros Didáticos de Geografia, já que ele possui um papel significativo no processo de ensino-aprendizagem, principalmente nas escolas públicas. Na mesma perspectiva, ressalta-se a importância da abordagem da temática Pobreza nos Livros Didáticos de Geografia, a fim de contribuir com uma atuação docente que promova a desconstrução de uma visão estigmatizadora das formas de pobreza e de exclusão social.

\section{REFERÊNCIAS}

ALMEIDA, Luana Costa. As desigualdades e o trabalho das escolas: problematizando a relação entre desempenho e localização socioespacial. Revista Brasileira de Educação, Rio de Janeiro, v. 22 n. 69 abr./jun. 2017.

ALMEIDA, Valdeci Ferreira. Análise do Conteúdo Cidade e o Livro Didático. In: IX FÓRUM NACIONAL NEPEG DE FORMAÇÃO DE PROFESSORES DE GEOGRAFIA, 3, 2018, Caldas Novas. Anais... Caldas Novas: UFG, 2018. p. 325-333.

ARROYO, M.G. Pedagogias em movimento: o que temos a aprender dos Movimentos Sociais? Currículo sem Fronteiras, Belo Horizonte, v.3, n.1, p.28-49, jan. /jun. 2003. 
BRASIL. Base Nacional Comum Curricular (BNCC). Educação é a Base. Ensino Médio, Brasília, MEC/CONSED/UNDIME, 2017a. Disponível em: http://basenacionalcomum.mec.gov.br/images/historico/BNCC_EnsinoMedio_embaixa _site_110518.pdf. Acesso em: 25 jan. 2020.

BRASIL. Fundo Nacional de Desenvolvimento da Educação. Programas do Livro PNLD Histórico. 2017b. Disponível em: http://www.fnde.gov.br/programas/programas-dolivro/pnld/remanejamento/item/518-hist\%C3\%B3rico?highlight=WyJlc2NvbGEiXQ==. Acesso em: 24 jan. 2020.

BRASIL. Ministério da Educação. PNLD 2018: Guia de Livros Didáticos Geografia Ensino Médio. Ministério da Educação. Brasília: MEC Secretária de Educação Básica SEB - Fundo Nacional de Desenvolvimento da Educação. Brasília, DF: Ministério da Educação, Secretária de Educação Básica, 2017c.

CASTROGIOVANNI, Antônio Carlos; GOULART, Lígia Beatriz. A questão do livro didático em geografia: elementos para uma análise. In: CASTROGIOVANNI, Antônio Carlos et al. (Org.) Geografia em sala de aula: prática e reflexões. 5. ed. Porto Alegre: Editora da UFRGS/Associação dos Geógrafos Brasileiros - seção Porto Alegre, 2010, p. 133136.

CAVALCANTI, Lana de Souza. Bases teórico-metodológicas da geografia: uma referência para a formação e a prática de ensino. In: CAVALCANTI, Lana de Souza (Org.). Formação de professores: concepções e práticas em Geografia. Goiânia: Editora Vieira, 2006, p. 27-49.

COUTO, Marcos Antônio Campos. Base Nacional Comum Curricular - BNCC Componente curricular: geografia Parecer Crítico, 2017a. Disponível em: $\quad$ http://basenacionalcomum.mec.gov.br/documentos/relatoriosanaliticos/pareceres/Marcos_Antonio_Campos_Couto.pdf. Acesso em: 26 jan. 2020.

COUTO. Para a crítica da Geografia que se ensina através dos Livros Didáticos. In: TONINI, Ivaine Maria et al (orgs.). O Livro Didático de Geografia e os desafios da docência para a aprendizagem. Ponto Alegre: Sulinas, 2017b, p. 191-220.

DALFOVO, M. S.; LANA, R. A.; SILVEIRA, A. Métodos quantitativos e qualitativos: um resgate teórico. Revista Interdisciplinar Científica Aplicada, Blumenau, v. 2, n. 4, p. 01- 13, 2008. Disponível em: https://www.academia.edu/download/37563682/metodos_quantitativos_e_qualitativo s_um_resgate_teorico.pdf. Acesso em: 01 fev. 2020.

DEON, A. R. Educação Escolar e Formação Cidadã: possibilidades de análise a partir do livro didático de Geografia. Revista Brasileira de Educação em Geografia, Campinas, v. 8, n. 15, p. 39-62, jan./jun. 2018. 
FIRMINO, Lerissa Corrêa; MARTINS, Rosa Elisabete Militz Wypyczunski. Imagensclichês e Livros Didáticos: reflexão para o ensino de Geografia. In: TONINI, Ivaine Maria et al (orgs.). O Livro Didático de Geografia e os desafios da docência para a aprendizagem. Ponto Alegre: Sulinas, 2017, p. 103-112.

FREIRE, Paulo. Pedagogia do oprimido. 66. ed. Rio de Janeiro: Paz e Terra, 2018.

KNECHTEL, Maria do Rosário. Metodologia da pesquisa em educação: uma abordagem teórico-prática Metodologia da pesquisa em educação dialogada. Curitiba: Intersaberes, 2014.

LADEIRA, Francisco Fernandes; LEÃO, Vicente de Paula. Livro didático e o ensino de Geopolítica para além do discurso midiático. In: TONINI, Ivaine Maria et al (orgs.). Geografia e livro didático para tecer leituras de mundo. São Leopoldo: Oikos, 2018, p. 197-208.

LAJOLO, Marisa. Livro didático: um (quase) manual de usuário. Em Aberto, Brasília, v. 16, n. 69, p. 3-9, jan./mar. 1996. Disponível em: http://rbep.inep.gov.br/ojs3/index.php/emaberto/article/view/2368/2107. Acesso em: 01 fev. 2020.

MANFIO, V.; SEVERO, M. D.; WOLLMANN, C. A. Discutindo a cidade em sala de aula: algumas considerações. In: SIMPÓSIO DE ESTUDOS URBANOS (SEURB): A DINÂMICA DAS CIDADES E A PRODUÇÃO DO ESPAÇO, 2., 2013, Paraná. Anais... Paraná: UEP, 2013, p. 30-42.

MARTINEZ, Rogério; GARCIA, Wanessa. \#Contato Geografia: ensino médio. São Paulo: Quinteto editorial, 2016.

MARTINS, D.; BIGOTTO, F.; VITIELLO, M. Geografia no Cotidiano: ensino médio. Curitiba: Base Editorial, 2016.

MOREIRA, Herivelton; CALEFFE, Luiz Gonzaga. Metodologia da pesquisa para professor pesquisador. Rio de Janairo: DP\&A, 2006.

NETTO, José Paulo; BRAZ, Marcelo. Economia política. Uma introdução crítica. São Paulo: Cortez, v. 1, 2006.

OLIVEIRA, Aldo Gonçalves; GIORDANI, Ana Claudia Carvalho. Guia do Livro Didático: textualidades em tensões. In: TONINI, Ivaine Maria et al (orgs.). 0 Livro Didático de Geografia e os desafios da docência para a aprendizagem. Ponto Alegre: Sulinas, 2017, p. 25-37.

OLIVEIRA, Karla Annyelly Teixeira. Saberes docentes e a Geografia Urbana Escolar. 2008. p.142. Dissertação (Mestrado em Ciências Humanas) - Universidade Federal de Goiás, Goiânia, 2008. 
RICHTER, D. Raciocínio Geográfico e Mapas Mentais: A leitura espacial do cotidiano por alunos do Ensino Médio. 2010. 335 f. Tese (Doutorado em Geografia) Faculdade de Ciências e Tecnologia, Universidade Estadual Paulista, Presidente Prudente, SP, 2010.

RIBEIRO, E. C. da. A contribuição do ensino de Geografia para a formação da cidadania nos alunos das escolas rurais no município de Rio Verde - GO. 2015. 113 f. Dissertação (Mestrado em Geografia) - Universidade Federal de Goiás, Jataí, 2015.

SAAB, T. B. A Pobreza e o Currículo: Permanências e Ausências nos Documentos Oficiais de Geografia. Revista de Ensino, Educação e Ciências Humanas, Londrina, v. 19, n. 03, p. 371-378, 2018.

SANTOS, Milton. Pobreza Urbana 3. ed. São Paulo: Edusp, 2009.

TONINI, Ivaine Maria; GOULART, Ligia Beatriz. Desafios para potencializar o Livro Didático de Geografia. In: TONINI, Ivaine Maria et al (orgs.). O Livro Didático de Geografia e os desafios da docência para a aprendizagem. Ponto Alegre: Sulinas, 2017, p. 259-271.

TOZONI-REIS, Marília Freitas de Campos. Metodologia da pesquisa científica. Curitiba: IESDE, 2007.

VALLERIUS, Daniel Mallman; SANTOS, Leovan Alves dos. Os Livros Didáticos como potencializadores do trabalho com os conceitos geográficos em sala de aula. In: TONINI, Ivaine Maria et al (orgs.). O Livro Didático de Geografia e os desafios da docência para a aprendizagem. Ponto Alegre: Sulinas, 2017, p. 221-238.

VITIELLO, Márcio Abondanza. A Geografia censurada: cerceamento à produção e à distribuição de livros didáticos. Curitiba: Aprris, 2018. 